\title{
Espacio y territorio en perspectiva antropológica. El caso de los purhépechas de Nurío y Michoacán en México
}

\section{Space and territory from an anthropological perspective. The case of the Purhépechas of Nurío and Michoacán in Mexico}

Recibido: 12 de diciembre de 2010

Álvaro Bello M. ${ }^{1}$

Aprobado: 15 de marzo de 2011

\section{Resumen}

En este artículo se analizan algunas perspectivas teóricas en torno a las categorías de territorio y espacio en contextos indígenas. Se trata de un análisis que intenta revisar las perspectivas tradicionales que vinculan territorio, práctica política y etnicidad en contextos indígenas. El problema es abordado en la perspectiva de la antropología política y la geografía del territorio, y toma como ejemplo el caso de los purhépechas de Michoacán en México. El desarrollo de este caso es relevante para la temática del territorio, pues Michoacán y lo purhépechas han sido un verdadero "laboratorio" de la antropología mexicana y norteamericana para aplicar conceptos y enfoques como "estudios de área", "regiones de refugio" o "región indígena". Por ello, es pertinente un análisis que permita revisar y cuestionar los supuestos que han estado a la base de dichas categorizaciones a partir de una perspectiva más centrada en los sujetos y sus formas de vivir y representar el espacio y el territorio.

Palabras clave: territorio, espacio, etnicidad.

\begin{abstract}
This article analyses some theoretical perspectives about the categories of territory and space in indigenous contexts. To do this it attempts to review the traditional perspectives which link territory, political practice and ethnicity in indigenous contexts. The problem is addressed from the perspective of political anthropology and territorial geography, and takes as an example the case of the Purhépechas of Michoacán in Mexico. The development of this case is important for the subject of territory, since Michoacán and the Purhépechas have been a real "laboratory" of Mexican and North American anthropology for the application of concepts and focuses such as "area studies", "refuge regions" or "indigenous regions". This accounts for the relevance of an analysis which reviews and questions the assumptions which have been at the base of these categorisations, starting from a perspective which is more centred on the subjects, their way of life, and how they represent space and territory.
\end{abstract}

Key words: territory, space, ethnicity

Dr. en Antropología, Escuela de Antropología, Universidad Católica de Temuco. Correo: abellom@uct.cl 
Introducción

El territorio no es una realidad constituida fuera de la historia y las prácticas de los sujetos, por el contrario, se trata de una realidad creada a partir de la apropiación y representación que las personas hacen del espacio $^{2}$. Este artículo se refiere a las formas de apropiación instrumental y simbólica del espacio, dicho proceso se produce dentro de un marco histórico específico y a partir de las estructuras socioculturales en las que están inmersos los sujetos.

Aunque las formas de apropiación instrumental y simbólica del espacio aparecen a simple vista como ámbitos separados, en realidad son parte de un mismo proceso social y cultural. La apropiación instrumental, manifestada en el uso y control efectivo del territorio, tiene como soporte el medio físico y geográfico, de esa apropiación derivan representaciones y significados que dan sentido a las prácticas espaciales de los sujetos ${ }^{3}$. A su vez, la apropiación simbólica del espacio expresadas por ejemplo a través de las redes de parentesco, el sentido de pertenencia, la topofilia o apego al territorio, o los proyectos etnopolíticos con base en el territorio, constituyen expresiones de la apropiación simbólica que crean realidades objetivas para las personas, son guías para la acción, mundos de sentido común, constituidos a través de disposiciones y largos procesos de interiorización ${ }^{4}$.

La antropología ha abordado desde sus orígenes las relaciones entre cultura, sociedad y espacio, sin embargo, el lugar que ha ocupado el territorio en el análisis de los fenómenos antropológicos ha variado en función de las diversas perspectivas teóricas en uso. En general las distintas tradiciones antropológicas han enfatizado las interrelaciones y vínculos de las estructuras y procesos locales, regiona- les y globales, pero sobre todo las apropiaciones materiales del espacio, así como la lógica euclidiana de representación, comprensión y uso del espacio por parte de los sujetos sociales.

El espacio también fue visto por la antropología como parte de los esquemas que organizaban la cultura. Malinowski, por ejemplo, señalaba la necesidad de comprender los fenómenos de la cultura a partir de un área geográfica perfectamente delimitada. El punto extremo de esta postura está en su propia obra que busca la comprensión de los procesos culturales en sociedades aisladas como los indígenas de las islas Trobriand. Pero incluso ya desde Boas se había planteado que las culturas tenían una expresión espacial que las demarcaba con claridad y que las diferenciaba respecto de otras culturas. Esta tendencia a buscar un punto de encuentro entra la cultura y el espacio prosiguió a lo largo de los años y se reflejó de forma nítida en una parte importante de la antropología cultural norteamericana. En los años cincuenta los llamados estudios de área inspiraron, por ejemplo, el trabajo del norteamericano Julian Steward, quien señalaba que las culturas tenían expresiones espaciales organizadas en diversos niveles de integración que iban desde el plano local o de la comunidad pasando por la región hasta llegar a los espacios nacionales ${ }^{5}$. Estas ideas influenciaron fuertemente a la antropología mexicana y a las políticas indigenistas, de hecho, la idea de los niveles de integración influyó en las definiciones de región utilizadas hasta hace pocos años. El concepto de región vinculado al factor económico como mecanismo de integración tuvo una gran aceptación y tendió a influir en la explicación de los fenómenos sociales y culturales ${ }^{6}$. La idea de áreas centrales y áreas periféricas dentro de una región eran una expresión de la dinámica económica de un espacio con un correlato en el plano de la cultura.

$2 \quad$ Claude Raffestin (1980), Pour une geographie du pouvoir, Paris, Librairies Techniques.

3 Emilia Velázquez (2001), "El territorio de los popolucas de Soteapan, Veracruz: transformaciones en la organización y apropiación del espacio", en Relaciones N ${ }^{\circ} 87$, vol. XII, pp. 15-47.

4 Pierre Bourdieu (1991), El sentido práctico, Madrid, Taurus.

5 Véase Julian Steward (1955), Teoría y práctica de los estudios de áreas, Washington D.C., Unión Panamericana y Julian Steward (1979), "Levels of sociocultural integration: An operational concept", en Cultural Change. The Metodology of multilineal evolution, Chicago, University of Illinois Press.

6 Guillermo de la Peña (1988), "Los estudios regionales", en Carlos García Mora (coord.), La antropología en México, Panorama histórico $\mathrm{N}^{\circ} 4$, Cuestiones medulares (Etnología y antropología social), México, INAH. 
En los últimos años se ha seguido un derrotero diferente que pretende romper con el dualismo hegemónico que dominó las ciencias sociales durantes décadas y que tiene su mejor expresión en el debate sobre la dicotomía naturaleza y cultura. Trabajos más recientes han reconocido que la naturaleza y el espacio son construcciones sociales en permanente cambio y que varían según las especificidades culturales y los contextos históricos en que se insertan los sujetos ${ }^{7}$. Dentro de este marco han adquirido renovada importancia los conceptos de espacio, lugar, ${ }^{8}$ territorio y paisaje, que desde la antropología, la arqueología y la geografía ${ }^{9}$, han tendido a ser definidos más en función de la cultura y la sociedad que solo desde los aspectos físicos o geomorfológicos ${ }^{10}$. En este sentido parece necesario avanzar en categorizaciones que indaguen en los significados que le asignan los propios sujetos a partir de sus experiencias, valores y condiciones de existencia. Un ejemplo de este cambio es el uso actual del concepto de región, hasta hace algún tiempo definido casi exclusivamente desde el ámbito económico ${ }^{11}$. Últimamente se ha avanzado en una idea de región, que teniendo como respaldo su materialidad, cobra realidad en la subjetividad, de tal manera que desde hace algunas décadas se ha definido la región como un "espacio vivido"12, idea que pone el acento en los campos sociales, en la cognición y vivencia del espacio por parte de los sujetos.
Lo mismo ha ocurrido con el concepto de comunidad que ha sido revisado a la luz de los nuevos debates sobre la cultura y los significados que las personas le atribuyen al espacio. Abandonadas hace tiempo las visiones estáticas y orgánicas de comunidad, en la actualidad algunos autores prefieren hablar de ella como una construcción simbólica que, sustentada en una base material, es pensada y vivida a partir de símbolos, valores, creencias y prácticas sociales y culturales compartidas por el grupo ${ }^{13}$. Las redes de parentesco, las interacciones sociales y las múltiples espacialidades construidas por los procesos de movilidad de los sujetos, estructuran redes que dan concreción a territorios específicos no sometidos a los mecanismos tradicionales, euclidianos, de constitución espacial.

Un campo donde se ha desarrollado con notoriedad la relación entre cultura y espacio es en los estudios sobre las identidades. Aunque algunos de estos estudios han retornado a temas que parecían superados con los planteamientos de Fredrik Barth ${ }^{14}$, los grupos étnicos siguen siendo definidos por su apego a la tierra o sus vínculos primordiales con el territorio de sus ancestros. Incluso algunos autores todavía esgrimen la idea funcionalista de que la posesión de territorios para los grupos étnicos es fundamental en la mantención de su cohesión como grupo ${ }^{15}$, lo que parece discutible a la luz de los estudios sobre

Un ejemplo de esta perspectiva se encuentra en los trabajos de Philippe Descola (2001), "Construyendo naturalezas, ecología simbólica y práctica social”, en Philippe Descola y Gísli Pálsson (coord.), Naturaleza y sociedad, perspectivas antropológicas, México, Siglo XXI.

8 Véase por ejemplo la distinción que De Certeau hace de espacio y lugar. Michel De Certeau (2000), La invención de lo cotidiano, I Artes de Hacer, México, Universidad Iberoamericana, Instituto Tecnológico de Estudios Superiores de Occidente.

9 Odile Hoffmann y Fernando Salmeron (1997), "Introducción. Entre representación y apropiación, las formas de ver y hablar del espacio", en Odile Hoffmann y Fernando Salmeron (Coords.), Nueve estudios sobre el espacio. Representación y formas de apropiación, México, CIESAS, ORSTOM.

10 Eric Hirsch (1997), "Introduction: Landscape: Between place and space”, en Eric Hirsch and Michael O’Hanlon (ed.), The anthropology of landscape, perspectives on place and space, Oxford, Clarendon Press; Mike Crang (1998), Cultural Geography, London, Routledge y Mike Crang and Nigel Thrift (2000), Introduction, en Mike Crang and Nigel Thrift (ed.), Thinking space, London, Routledge.

11 Sobre las distintas perspectivas de región que han atravesado los estudios antropológicos en México, véase: Carmen Viqueira (2001), El enfoque regional en antropología, México, Universidad Iberoamericana.

12 Armand Frémont (1976), La région, espace vécu, Paris, Presses Universitaires de France.

13 Anthony Cohen (1989), The symbolic construction of community, London, Routledge.

14 Para este autor, el grupo étnico es una forma de organización social que se define no por sus características objetivas o manifiestas (la lengua, la cultura, la vestimenta, etc.) sino que por las fronteras étnicas, esto es, por las diferencias objetivas que los propios actores definen como significativas, en Fredrik Barth (1976), Los grupos étnicos y sus fronteras, México, Fondo de Cultura Económica, p. 15.

15 George De Vos (1995), "Ethnic pluralism: conflict and acommodation", en Lola Romanucci-Ros y George De Vos (eds.), Ethnic identity, creation, conflict and acommodation, USA, Altamira Press. 
comunidades migratorias, transnacionales o extraterritoriales. Oehmichen, por ejemplo, señala que la migración no es necesariamente un indicador de desterritorialización, pues el territorio, en este caso la comunidad, para los migrantes, sigue siendo un lugar de anclaje para la construcción de sus identidades ${ }^{16}$. En una publicación más reciente la autora señala incluso que con frecuencia la comunidad puede seguir operando en uno o más lugares, pues los migrantes tienden a mantener sus vínculos con el lugar natal, y agrega que la comunidad puede operar a través de redes dispersas a través del espacio geográfico ${ }^{17}$.

De este modo, las relaciones entre cultura, territorio y sociedad son creaciones históricas y sociales y no el resultado de factores "naturales" o determinaciones culturales ${ }^{18}$. El territorio, según Giménez, conjuga distintas dimensiones, pues constituye, por una parte, un "espacio de inscripción de la cultura", lo que equivale a una de sus formas de objetivación; sirve como marco o área de distribución de instituciones y prácticas culturales espacialmente localizadas; y, por último, puede ser apropiado subjetivamente, como objeto de representación y de apego afectivo, como símbolo de pertenencia socioterritorial. ${ }^{19}$

Como ya he sugerido en las páginas precedentes, y siguiendo con la argumentación del párrafo anterior, parecen plausibles los planteamientos de Bourdieu para comprender el modo en que los sujetos incorporan los elementos objetivos de la cultura como elementos subjetivados a través de un largo proceso de inculcación. La objetivación del espacio es resultado de la interiorización y subjetivación de procesos objetivos, lo que Bourdieu llama habitus. El habitus, señala Bourdieu, realiza un necesario proceso de inculcación y apropiación para que los productos de la historia colectiva, que son estructuras objetivas, consigan reproducirse como disposiciones duraderas y ajustadas ${ }^{20}$. Cada grupo realiza estos ajustes en concordancia con sus experiencias, contextos y especificidades, lo que significa que cada grupo otorga significados diferentes a un hecho aparentemente objetivo y material como puede ser el territorio ${ }^{21}$.

\section{El territorio como espacio apropiado}

Los estudios agrarios y antropológicos en contextos indígenas han privilegiado visiones sobre el territorio que aluden a las formas de apropiación instrumental dentro de las que destaca la constitución de la propiedad de la tierra a través de las luchas agraristas, desplazando a un lugar secundario los significados y las formas de apropiación simbólica que los sujetos hacen en distintos momentos y en función de sus especificidades culturales. Es decir se ha mirado el territorio desde fuera y no desde una perspectiva de segundo orden, esto es, de la forma en que lo ven, lo interpretan y los representan los propios sujetos. En el caso de México esta tendencia está comenzando a ser revertida a partir de la aparición de nuevos estudios sobre la construcción simbólica de los territorios étnicos ${ }^{22}$. De esta manera, es posible estudiar y explicar simultáneamente las distintas dimensiones y significados que tiene el territorio para los sujetos a partir de una conceptualización y una metodología que

16 Cristina Oehmichen (2001), "La comunidad extendida: propuesta para una reflexión antropológica”, en Antropológicas, № 17, pp. 49-57.

17 Cristina Oehmichen (2005), Identidad, género y relaciones interétnicas, Mazahuas en la ciudad de México, México, UNAM, IIA, PUEG.

18 Akhil Gupta y James Ferguson (1999), "Culture, power, place: Ethnography at the end an era", en Akhil Gupta y James Ferguson (eds.), Culture, power, place, Durham and London, Duke University Press.

19 Gilberto Giménez (2000), "Territorio, cultura e identidades: la región socio-cultural", en Rocío Rosales Ortega (coord.), Globalización y regiones en México, México, UNAM, Facultad de Ciencias Políticas y Sociales, Porrúa, pp. 29-30. También Gilberto Giménez (1994), "Comunidades primordiales y modernización en México", en Gilberto Giménez y Ricardo Pozas (coord.) Modernización e identidades sociales, México, UNAM, IIS, Instituto Francés de América Latina; y Gilberto Giménez (2001), "Cultura, territorio y migraciones: aproximaciones teóricas", en Alteridades, año 11, № 22, julio-diciembre, pp. 5-14.

20 Bourdieu, op. cit., p. 99.

21 David Harvey (1998), La condición de la posmodernidad. Investigación sobre los orígenes del cambio cultural, Buenos Aires, Amorrortu.

22 Alicia Barabas (2003), "Introducción: Una mirada etnográfica sobre los territorios indígenas simbólicos", en Alicia Barabas (coord.), Diálogos con el territorio. Simbolizaciones sobre el espacio en las culturas indígenas, México, INAH. 
integre las dimensiones simbólicas y materiales que los sujetos poseen del espacio y el territorio. Un ejemplo de que es posible hacer trabajos en esta línea se encuentra en la obra del historiador Marcello Carmagnani sobre los indios de Oaxaca en los siglos XVII y XVIII23. En esta obra el autor presenta el proceso de reconstitución de la identidad indígena en Oaxaca dentro del cual la reorganización del espacio juega un papel fundamental, pues a partir del territorio, que es el espacio simbolizado, los indígenas oaxaqueños logran defenderse de las amenazas coloniales y de los enemigos internos.

En Nurío, pequeña población ubicada en las tierras altas del Estado de Michoacán en México, los conflictos agrarios han sido uno de los ejes desde el que se ha organizado la comunidad agraria, como forma de tenencia de la tierra, y la reconstrucción de la comunidad indígena, como cuerpo social y comunidad política ${ }^{24}$. Como en otras comunidades indígenas, el territorio de Nurío entrelaza diversas formas de apropiación del espacio: una instrumental, identificada con la lucha por la tierra y los conflictos agrarios, y otra simbólica que, desde la etnicidad, pone el acento en los procesos simbólicos, en las representaciones espaciales basadas en la cultura, el mito y en la construcción de una topografía étnica del espacio donde predominan los geosímbolos y las marcas de alteridad del espacio. Ambas formas de apropiación emergen en uno u otro momento de la historia reciente de la comunidad de Nurío, sin embargo, cada una es también parte de la otra, por lo que la separación entre lo simbólico y lo material es más bien analítica y metodológica que real. La visión sobre el espacio, el territorio y las formas de apropiación simbólica e instrumental se basan en los planteamientos que hace algunas décadas hiciera el geógrafo suizo Pierre Raffestin ${ }^{25}$.
Para Raffestin, espacio y territorio son nociones diferenciadas, distintas pero complementarias. El espacio se encuentra en una posición de anterioridad al territorio ${ }^{26}$. El territorio, es generado a partir del espacio como resultado de una acción conducida por un "actor sintagmático" (acteur syntagmatique), que es un actor realizador de un programa. En su apropiación o abstracción de un espacio el actor "territorializa" el espacio. Un espacio territorializado es un espacio en el que se proyecta la acción de los sujetos, la plataforma donde se desenvuelve la energía y la información social. En el territorio se despliegan todas las relaciones marcadas por el poder. El autor recalca que el espacio es preexistente a toda acción, es una suerte de materia prima, es la realidad preexistente a todo conocimiento y a toda práctica, el objeto sobre el cual los actores manifiestan sus acciones intencionadas. El territorio tiende a ubicarse sobre el espacio, pero no es el espacio, es más bien una "producción" sobre él. Esta producción es el resultado de las relaciones inscritas dentro de un campo de poder.

El geógrafo Raffestin señala que producir una representación del territorio es en sí mismo una apropiación, un control dentro de los límites de una conciencia, así toda proyección en el espacio construida como representación, revela la imagen de un territorio, de una red de relaciones. Asimismo, toda proyección es sostenida por un conocimiento y una práctica, lo que supone la posesión de códigos, símbolos y "sistemas sémicos". Es a través de un conjunto de sistemas sémicos que se realiza la objetivación del espacio dentro de los procesos sociales. En este esquema, los límites del espacio son "celdas" del sistema sémico movilizadas por el representador.

El territorio como imagen y representación puede ser un instrumento de poder. Des-

\footnotetext{
23 Marcello Carmagnani (2004), El regreso de los dioses. El proceso de reconstitución de la identidad étnica en Oaxaca, siglos XVII y XVIII, México, Fondo de Cultura Económica.

24 En la investigación distingo entre comunidad como un estatus jurídico de tenencia de la tierra, la comunidad agraria, y la comunidad como estatus social y cultural, la comunidad indígena. Sobre esta cuestión véase: Arturo Warman (1985), "Notas para una redefinición de la comunidad agraria", en Revista Mexicana de Sociología, № 3 (julio-septiembre); y Ludka de Gortari (1997), "Comunidad como forma de tenencia de la tierra", en Estudios Agrarios № 8, (julio- septiembre).

25 Raffestin, op. cit.

26 Raffestin, op. cit., pp. 129-130.
} 
de esta perspectiva, las representaciones son un motor de la acción colectiva, son guías que se superponen al objeto mismo representado. La dirección o aun la distancia que tome la representación del objeto o de la "realidad" está en directa relación con los sujetos a que se vincula el sistema de representaciones, con el control que estos ejercen sobre él, por la hegemonía que se pone en disputa en torno a la imagen que se desea imponer del territorio.

Las representaciones del territorio son fundamentales para comprender los pro- cesos de construcción territorial, sus formas de apropiación. La apropiación se refiere al ejercicio y forma de dominio o control que lo sujetos hacen de un determinado territorio. Desde la época moderna las representaciones del territorio han estado ligadas a la cartografía, es decir, a la sintaxis euclidiana que han modelado los comportamientos del poder con relación al territorio. Sobre esto, Raffestin señala que la sintaxis euclidiana ha sido de una enorme eficacia, pues se fundamenta en tres elementos básicos y completamente "palpables": la superficie, el punto y la línea.

La producción de territorio a través de sus formas de apropiación

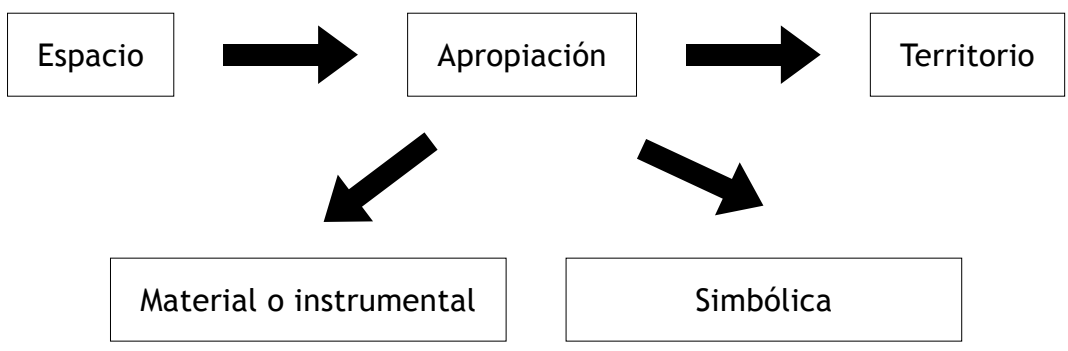

La apropiación material o instrumental del territorio se manifiesta a través del uso, control, tenencia y propiedad de porciones determinadas de espacio ${ }^{27}$ y se produce a partir de sus representaciones euclidianas. Los actores realizan una partición de la superficie, estableciendo mallas o mailles (superficies), implantando nodos (puntos), y construyendo redes (líneas). En Nurío, calles, barrios, áreas de cultivo, tierras comunales y de pastoreo comprenden un complejo de puntos y redes que conforman la malla de ocupación material del espacio. También lo conforman los deslindes, las mojoneras y los límites comunales que separan a Nurío de las otras comunidades o que los unen en una red de comunidades que conforman el territorio de la Meseta. En los últimos años estas mallas se han ampliado como producto de los flujos migratorios a los Estados Unidos, así los nurienses han implantado nodos y han construido redes que unen al pueblo de Nurío con localidades tan alejadas como Sedalia, Missouri, lugar donde habita más de un centenar de nurienses que traba- jan en procesadoras de alimentos y fábricas de ropa.

Por otro lado, el conflicto agrario ha significado que las representaciones euclidianas del espacio jueguen un papel fundamental, los planos, mapas y títulos primordiales, por ejemplo, han servido a las comunidades como instrumentos de poder, como evidencias objetivas de sus demandas. Lo mismo la posesión y explotación de los espacios en disputa. Durante la época del conflicto agrario uno de los principales argumentos y pruebas de las partes en litigio era la explotación efectiva, la posesión concreta, que habían hecho generaciones de personas de una misma comunidad sobre un espacio o lugar determinado.

El procedimiento anterior constituye la parte visible de los procesos de apropiación espacial, pero las mallas, los nodos y las redes pueden ser "invisibles" o simbólicos. Para los actores tales formas exteriorizan procesos interiorizados, como la pertenencia, el pa- 
rentesco, los proyectos políticos o la imagen de un espacio común, exclusivo o sagrado. La sacralización del espacio puede producirse a través de un complejo proceso de implantación de nodos que representan lugares significativos para la comunidad. En Nurío, por ejemplo, se ha producido un activo proceso de implantación de nodos o geosímbolos que reafirman la historia antigua y mítica de la comunidad, pero que además sirven como referencias para legitimar la posesión de la tierra como un hecho evidente e incontestable. Cuevas sagradas, ruinas prehispánicas, lugares con contenidos mágico-religioso se distribuyen profusamente en los sectores aledaños a las áreas de conflicto. En los discursos, las personas señalan que la defensa de la tierra tiene que ver también con la defensa de esos geosímbolos que le dan sentido y continuidad a la comunidad como cuerpo social.

Desde la perspectiva de Raffestin, la territorialidad se conforma a partir de relaciones sociales entre distintos actores, relaciones que son mediatizadas por el territorio, y que pueden ser simétricas o asimétricas ${ }^{28}$ organizadas en función de las disputas por la obtención de beneficios y recursos a los que logran acceder mediante la constitución de liderazgos y grupos faccionales que luchan incluso al interior de la comunidad.

Las relaciones de los grupos humanos con el territorio, sus territorialidades, pueden estar conformadas por un sentido de identidad espacial, de exclusividad con relación al territorio y de una compartimentación de las interacciones con un territorio determinado. Estas relaciones se tornan complejas cuando las territorialidades de un grupo se interceptan con las de otros grupos. Los grupos humanos son heterogéneos y no todos los individuos perciben el territorio de la misma forma ni se relacionan en los mismos términos con un espacio determinado. Por ello, las luchas de poder o la conformación de liderazgos vinculadas al territorio tienen una enorme importancia en la construcción de visiones consensuadas sobre el territorio. De esta manera, la con- formación de estructuras de poder al interior de un colectivo logran romper la tendencia del grupo a interpretar el espacio de manera diversa y dispersa. Sin embargo, los procesos de modernización, la mercantilización y el neoliberalismo en el campo plantean nuevas tensiones a los intentos de los grupos de poder comunales, pues paulatinamente surgen individuos u otros grupos que intentan romper con las visiones y apropiaciones consensuales y hegemónicas que organizan el territorio.

Por último, al hablar de los significados del territorio, necesariamente debo referirme a los símbolos y a la producción simbólica, pero no como algo aislado de la realidad, sino como procesos vinculados a los hechos reales y a los sujetos concretos que producen, usan y dan vida a los símbolos ${ }^{29}$. El territorio es un producto social y cultural, resultado de las relaciones sociales en contextos específicos, es lo que John B. Thompson denomina "formas simbólicas", algo que para las personas expresa determinados significados dentro de procesos y contextos estructurados socialmente ${ }^{30}$. De esta manera, en este estudio el territorio es un fenómeno y un objeto de la cultura y los fenómenos de la cultura son significativos, tanto para los actores como para los analistas, como bien señala Thompson.

Territorio, indigenismo y antropología: el caso del territorio purhépecha de Michoacán, México.

El indigenismo de Estado, la política de organización y administración de las diferencias culturales se desarrollaron en México a partir de una estrecha relación entre el conocimiento antropológico y un Estado que pretendía llevar a cabo un proyecto de nación. Ciencia y política actuaron de manera conjunta retroalimentándose mutuamente buscando el mismo objetivo: incorporar al indio a la nación. De esta manera hoy día es una hipótesis acabada la idea de que una parte importante de los procesos étnicos del siglo XX han contado con la contribución del propio Estado y, en este caso, la antropología. Las ciencias socia-

\footnotetext{
28 Raffestin, op. cit., p. 144.

29 Dan Sperber (1988), El simbolismo en general, Barcelona, Anthropos.

30 John B. Thompson (2002), Ideología y cultura moderna: Teoría crítica social en la era de la comunicación de masas, MéxiCO, UAM.
} 
les y la antropología en particular han tenido un papel fundamental en la compresión de los procesos territoriales que se imbrican con lo étnico. La antropología, sobre todo algunas de las corrientes que se desarrollan en la segunda mitad del siglo XX, tiene una importancia central en la construcción del indigenismo de Estado que nace en tierras michoacanas y que ve en los purhépechas el laboratorio para la construcción de sus postulados básicos. El caso más notorio es la regionalización de los purhépechas en cuatro regiones culturales (la Ciénega, la Cañada, la Laguna y la Sierra) que desde los ámbitos geográficos que ocupan en un determinado espacio o región pasan a ser entidades socioculturales sobre las cuales se estructura la labor del INI, primero, y luego, la acción colectiva de los purhépechas que a la vez construyen sus "nuevas" territorialidades sobre dicha base ${ }^{31}$.

La mayor parte de los estudios sobre los purhépechas, realizados por la antropología desde los años cuarenta en adelante y hasta hace una pocas décadas, han configurado a un sujeto definido desde fuera y a partir de un listado de elementos diacríticos como la lengua, el territorio o la región, la vestimenta, sus utensilios, su religión, sus casas y su folclore. Esta forma de definición concuerda con las concepciones de cultura vigentes en la época, donde el espacio y la región eran parte fundamental de los "rasgos" que constituían las configuraciones o esquemas culturales, según lo planteado por Ruth Benedict y las diferentes corrientes del culturalismo norteamericano.

En lo referente al espacio y el territorio de los purhépechas, cuestión que ya ha sido comentada en otros trabajos ${ }^{32}$, el llamado Proyecto Tarasco de 1940 juega un papel central ${ }^{33}$, sobre todo en cuanto a la construcción de la Sierra o Meseta Tarasca como un espacio con límites propios, aunque mal definidos a partir de una diversidad de criterios a veces extemporáneos, contradictorios o poco claros $^{34}$. A través del Proyecto Tarasco, así como de un sinnúmero de investigaciones y proyectos que le siguieron, el indigenismo construyó un discurso propio sobre la "región tarasca", recordemos por ejemplo el Proyecto de Moisés Sáenz en la Cañada de los Once Pueblos ${ }^{35}$, o la caracterización que Aguirre Beltrán hace de la Sierra Tarasca como una región que actúa como núcleo de la persistencia tarasca, como una "región de refugio", aunque en la práctica la Meseta es considerada como un espacio residual, como parte del área de escurrimiento de la cuenca del Tepalcatepec ${ }^{36}$, o algunos años después la propuesta sobre el sistema de mercados regionales de Durston ${ }^{37}$, que en lo sustancial recogen algunos planteamientos de Brand, West y Beals, y que integra algunos nuevos planteamientos de Foster ${ }^{38}$. En los años ochenta y bajo un renovado ecologismo cultural Espín ${ }^{39}$, a través del modelo de los pisos

$31 \quad$ Esta idea la he tomado de Luis Vázquez (2003), "Construcción y deconstrucción de los pueblos indígenas bajo el nuevo espíritu del capitalismo", en Memoria № 170, pp. 49-54.

32 Guillermo de la Peña; Thierry Link y Jaime Espin (1987), "Algunos temas y problemas en la antropología social del área purhépecha", en Antropología Social de la Región purhépecha, Zamora, El Colegio de Michoacán.

33 Daniel Rubin de la Borbolla y Ralph Beals (1940), "The Tarascan project: A cooperative enterprise of the National Polytecnic Institute, Mexican Bureau of Indian Affairs, and The University of California", American Anthropologist, XLII, pp. 708-712.

34 Si bien los trabajos del período tendieron a privilegiar el criterio lingüístico, otros incorporaron criterios arqueológicos, mientras que otro lo hicieron con criterios geográficos, económicos y sociales. Entre los trabajos que incorporan este tipo de criterios se encuentran: Donald Brand (1944); Daniel Rubin de la Borbolla (1946); Dan Stanislawski (1947), Tarascan political geography, American Anthropologist, vol. 49, pp. 46-55; Robert West (1948), Cultural geography of the modern tarascan area, Washington D.C., Institute of Social Anthropology, 7, Smithsonian Institution; Rudolf van Zantwijk (1974), Los servidores de los santos: la identidad social y cultural de una comunidad tarasca en México, México, INI-SEP; Ina Dinnerman (1974), Los tarascos, campesinos y artesanos de Michoacán, México, SEPSETENTAS; Pedro Carrasco (1976), El catolicismo popular de los tarascos, México SEPSETENTAS, entre otros.

35 Moisés Sáenz (1966 [1938]), Carapan, Morelia, Gobierno de Michoacán.

36 Gonzalo Aguirre Beltrán (1995 [1952]), Problemas de la población indígena de la cuenca del Tepalcatepec (vols. I y II), Obra Antropológica III, México, Fondo de Cultura Económica; Gonzalo Aguirre Beltrán (1991a [1953]), Formas de gobierno indígena, Obra Antropológica IV, México, Fondo de Cultura Económica; Gonzalo Aguirre Beltrán (1991b), Regiones de refugio, Obra Antropológica IX, México, Fondo de Cultura Económica.

37 John Durston (1992), Organización social de los mercados campesinos en el centro de Michoacán, México, INI, CONACULTA.

38 George Foster (1974), Las culturas tradicionales y los cambios técnicos, México, Fondo de Cultura Económica.

39 Espín, 1986a, op. cit.; 1987, op. cit. 
ecológicos, desarrolla un planteamiento que tendrá una gran difusión en México, la idea de los "centros rectores". Con estas ideas se asume la "regionalidad" de los purhépechas como un hecho real, sustancial y característico de su cultura y desde entonces va a estar presente en la regionalización de las estructuras y políticas del $\mathrm{INI}$, que recogen de forma literal la regionalización de este grupo étnico propuesta por el Proyecto Tarasco de Mauricio Swadesh. Esto no es raro si se recuerda que el Proyecto Tarasco fue presentado oficialmente en el Primer Congreso Indigenista, realizado en Pátzcuaro, Michoacán, en 1940.

En las próximas páginas analizo brevemente los discursos antropológicos sobre el territorio y la territorialidad purhépecha intentando establecer sus alcances heurísticos para comprender la forma en que la antropología ha contribuido a la construcción de un territorio indígena.

\section{La construcción antropológica del territorio purhépecha}

La antropología y la historiografía han contribuido a construir la imagen de un territorio purhépecha como un espacio relativamente continuo y homogéneo, articulado por características culturales y lingüísticas propias. Esta construcción del territorio purhépecha "desde fuera" ha puesto a la Meseta como eje y núcleo central de las representaciones que abordan la organización de lo purhépecha como asentado en una plataforma territorial claramente delimitada y relativamente homogénea. En mi opinión, esta influencia adquirió su mayor importancia a través de los estudios antropológicos realizados a partir de los años cuarenta, estudios que influyeron de manera fundamental en las visiones desarrolladas por el indigenismo mexicano y que se apoyaron en dos bases de argumentación: el registro arqueológico y la lengua. Ambos factores, en combinación, ayudaron a conformar las principales representaciones del "territorio tarasco" tanto en la perspectiva prehispánica como en su evolución posterior a partir del contacto con los europeos.

Desde los años cuarenta surgió un amplio interés por el estudio de la región tarasca como entonces se le denominaba a la región purhépecha ${ }^{40}$, en algún sentido este interés tomó la forma de laboratorio de distintas corrientes antropológicas que desde el principio se vincularon con el naciente indigenismo de Estado, ambos, el indigenismo y la antropología se construyeron y dialogaron mutuamente con base al conocimiento generado y a la aplicación de experiencias concretas en tierras purhépechas. Así, se desarrollaron un conjunto de investigaciones enmarcadas dentro de los denominados "estudios de áreas", línea desarrollada por la corriente antropológica de la ecología cultural, cuyo máximo exponente fue el antropólogo norteamericano Julian Steward, quien señalaba que las áreas o regiones culturales debían ser entendidas como lugares en que se desenvolvían las culturas o los llamados "conjuntos culturales". Se trataba de entender la cultura como un "patrón" que calzaba con un espacio o una región determinada. Así las comunidades o las regiones culturales eran estudiadas como "niveles de integración" o como "agregados territoriales" de culturas específicas ${ }^{41}$. Desde esta perspectiva se pensaba que eran las condiciones geográficas las que "protegían" o "conservaban" ciertos "rasgos culturales". Bajo estas perspectivas se hicieron numerosos estudios, dentro de los cuales el más importante, pese a quedar inconcluso por falta de fondos, fue el llamado "Proyecto Tarasco", realizado en tierras michoacanas a principios de los años cuarenta y que fue presentado oficialmente, como ya dije, durante la realización del Primer Congreso Indigenista en Pátzcuaro, Michoacán ${ }^{42}$. Incitados por los estudios de áreas, diversos

40 De hecho este exoetnónimo sigue siendo utilizado por los arqueólogos y por algunos antropólogos que niegan validez al etnónimo purhépecha.

41 Julian Steward, (1955), op. cit. En una línea similar se encuentra el trabajo Alfonso de Gortaire (1968), La región tarasca: estudio de integración de áreas, en Anuario Indigenista, vol. XXVIII, diciembre, pp. 25-32.

42 Véase Rubín de la Borbolla y Beals, op. cit. Como contraparte, la antropología británica intentó abrazar las denominaciones y conceptos territoriales de los propios sujetos, cuestionando las asignaciones externas y las construcciones antropológicas. Este es el caso de los trabajos de M. Fortes y E.E. Evans-Pritchard, sobre los sistemas políticos africanos, y las obras posteriores de E. Leach y M. Gluckman. Un trabajo clásico al respecto es el de Leach, Edmund (1977), Sistemas políticos de la Alta Birmania, Barcelona, Anagrama. Leach al igual que Max Gluckman reconocieron además las trasformaciones sobre la territorialidad "indígena" introducidas desde fuera por el colonialismo. 
investigadores se dieron a la tarea de levantar amplios estudios sobre la región tarasca.

Stanislawski señalaba, por ejemplo, que la cultura tarasca se había preservado por el aislamiento provocado por la geografía montañosa de la Sierra de Michoacán, situación que solo había sido rota por la construcción de nuevas vías camineras a fines de los años treinta. Este aislamiento, según el autor, no tenía como causa única la difícil geografía del área, sino también, una serie de factores históricos como la presencia al este del "Imperio Azteca".

El trabajo de West ${ }^{43}$ ha sido tal vez uno de los de mayor influencia en los "estudios tarascos", especial importancia han tenido los mapas incluidos en el texto, estos han ejercido una enorme influencia en la objetivación y representación del territorio purhépecha y de la Sierra en particular. El autor define la geografía cultural de los tarascos con base en la lengua hablada, según este criterio la región tarasca comprendía cuatro regiones geográficas: la Sierra, que comprende la mayor porción del territorio y que va desde la orilla occidental del Lago de Pátzcuaro hasta el este de la ferrovía Zamora-Los Reyes, mientras que las cuencas del Balsas-Tecapaltepec marcan su límite sur. Por el este, la Sierra limita con la sierra de Ozumatlán. En la época del estudio de West, la Sierra concentraba al $60 \%$ de la gente de habla tarasca o purhépecha. La segunda región geográfica tarasca es la del Lago de Pátzcuaro, que entonces contenía al $19 \%$ de la población de habla tarasca. Las regiones restantes estaban comprendidas por la Cañada de los Once Pueblos y por lo que West denomina como islas o remanentes de habla tarasca, especialmente en la zona norte noroeste del lago de Pátzcuaro (Tiríndaro, Tarejo y Naranja, Zacapu, Azajo, entre otros) - Cuanajo ubicado al sureste de la ciudad capital del estado, Morelia. Teniendo como base la lengua hablada, West consideraba que el territorio tarasco o purhépecha había disminuido drásticamente desde la época colonial ${ }^{44}$. West asume los límites mencionados por Stanislawski y Brand, como lo hará tam- bién Beals en 1969, que abarcaban más allá del Bajío de Guanajuato y de Jalisco, y reconoce como el centro, el corazón de la región tarasca a la Sierra y la zona comprendida por la zona del Lago de Pátzcuaro y Cuitzeo ${ }^{45}$. La concentración de la población en las tierras altas se debió, entre otras causas, al contagio de enfermedades traídas por los europeos que diezmaron a la población de las tierras bajas, lo que en el primer siglo de conquista significó una reducción al $25 \%$ de la población existente antes de la conquista. La población habría sido diezmada y desplazada por las entradas violentas de los conquistadores españoles, asimismo los mineros hispanos habrían destruido y deslocalizado a la población tarasca a través de la esclavitud y el sobretrabajo al que fueron sometidos. Los repartimientos de indios, organizados para proveer de mano de obra a las minas de plata del norte y del este en cambio surtieron escasos efectos sobre los pueblos de la sierra. Otro elemento que destaca West, tal vez el más importante en la dinámica de población y constitución de las regiones étnicas tarascas, fue a través de la relaciones cotidianas, la colonización y el vasallaje establecido por los españoles con los tarascos, esto ocurrió especialmente en las tierras bajas, en la Ciénaga de Zacapu, en Cuitzeo y en el delta del Lerma al este del Lago de Chapala. Las estancias y los repartimientos fueron establecidos después de la rendición pacífica de los tarascos en 1522. Los establecimientos de pueblos hispanos, localizado entremedio de los pueblos indios, sirvieron como centro de aculturación así como lugares de trabajo permanente para los indios. El mestizaje con otros grupos, como mulatos y negros, significó la pérdida progresiva de la lengua tarasca de los habitantes de las áreas mencionadas. Españoles y mulatos se avecindaron también en pueblos indios reorganizados (como Cuitzeo, Indaparapeo y Chilchota), en estos pueblos la población indígena quedó relegada a barrios o cuadras ${ }^{46}$.

Hacia 1948 los límites de la región tarasca, con base en la lengua hablada, estaban confinadas, según West, a la tierra fría: el

\footnotetext{
43 West, op. cit.

44 Ibid., p. 11.

45 Idem.

46 Ibid. p. 13
} 
Lago de Pátzcuaro y la Sierra. El autor señala que estas regiones junto con la Cañada, aparecen como un núcleo de resistencia contra la completa desaparición de la lengua nativa. A diferencia de Stanislawski, West creía que la mantención de la Sierra como un núcleo duro de la lengua tarasca no podía ser atribuible a la inaccesibilidad, pues desde temprano hubo rutas que atravesaron dicho territorio, el autor señala que la Sierra simplemente no fue atractiva para la explotación hispana. Hacia 1948, los municipios con mayor porcentaje de población de habla tarasca se ubicaban en la Sierra y en la Cañada, aunque la distribución de las tenencias era dispareja y en algunos casos aisladas.

La obra de Aguirre Beltrán, particularmente Problemas de la población indígena, publicada originalmente en 1952, y Formas de gobierno indígena, publicada por primera vez en 1953, son fundamental en el proceso de construcción antropológica del entonces territorio tarasco, hoy purhépecha ${ }^{47}$. La obra de Aguirre debe ser entendida, sin embargo, en un contexto distinto al de la antropología norteamericana, pues aunque se basa en varias de las obras citadas arriba, su objetivo es documentar un conjunto de procesos históricos y actuales que puedan servir de base para la modernización de la región a través de la acción integradora de la Comisión Tepalcatepec, uno de los primeros grandes proyectos estatales que buscó la integración de los purhépechas.

Para Aguirre Beltrán, la acción del indigenismo y los procesos de modernización podían ser un vehículo efectivo para la integración de los indígenas a la nación, esta idea tenía más sentido si se trataba de grupos que habitaban regiones de difícil acceso donde la acción del Estado y de la sociedad moderna no alcanzaban para sustituir o cambiar las costumbres indígenas a través de los procesos de aculturación. Aguirre Beltrán escribe su trabajo en los momentos precisos en que comenzaba a hacerse más efectiva la penetra- ción de la modernización urbana en la región de la Sierra ${ }^{48}$.

Los estudios de área vinculados a la práctica del indigenismo están ligados desde un principio a la figura de Lázaro Cárdenas, quien como gobernador del Estado y como Presidente de la República después, ejercerá una enorme influencia en las acciones que se emprendan hacia los grupos étnicos del país, esta labor se prolongará con los grandes programas implementados por el Estado y en los cuales Cárdenas seguirá teniendo una influencia clave aun años después de haber dejado la presidencia. Así ocurrirá con el Proyecto de la Comisión Cuenca del Tepalcatepec, durante los sexenios de Miguel Alemán (1946-1952) y Adolfo Ruiz Cortines (1952-1958). Este proyecto de infraestructura e irrigación, involucró a una gran parte de la región purhépecha y que se realiza con Lázaro Cárdenas como vocal ejecutivo de la Comisión, como más tarde lo será de la Comisión Río Balsas. La Comisión de Tepalcatepec alcanza sus mayores logros en momentos que el gobernador del Estado de Michoacán es Dámaso Cárdenas, hermano del primero. Es para esta Comisión que Gonzalo Aguirre Beltrán realiza su trabajo sobre $\mathrm{Mi}$ choacán, Problemas de la población indígena de la cuenca del Tepalcatepec y el capítulo sobre los purhépechas en Regiones de Refugio. Los trabajos de Aguirre Beltrán no solo van a nutrir los programas estatales, sino que a la misma antropología. La Meseta como "región de refugio" o como una región "más india" que el resto de las regiones purhépechas calará hondo en los imaginarios antropológicos sobre el territorio purhépecha y sobre los purhépechas mismos como un sujeto "regionalizado". Lo interesante es que aparte de la lengua y ciertas características geográficas, ni los autores ni los agentes estatales llegan a aclarar del todo qué otro factor hace de estas regiones entidades específicas, diferenciadas. Hasta el día de hoy, los propios purhépechas no reconocen la existencia de diferencias, incluso en el plano lingüístico, sin embargo, ellos mismos utilizan esa regionalización para

\footnotetext{
47 Gonzalo Aguirre Beltrán (1952), Problemas de la población indígena de la Cuenca del Tepalcatepec (vols. I y II), Obra Antropológica III, México, Fondo de Cultura Económica; y Gonzalo Aguirre Beltrán (1953), Formas de Gobierno Indígena, Obra Antropológica IV, México, Fondo de Cultura Económica.

48 Robert Kemper (1987), "Urbanización y desarrollo en la región tarasca a partir de 1940", en Antropología social de los Purhépechas, Zamora, El Colegio de Michoacán.
} 
organizarse y construir alianzas, como los vínculos más estrechos, por ejemplo entre los de la Meseta y la Cañada o la "vía propia" de los habitantes de la Laguna.

Dentro de los esquemas de análisis surgidos con el desarrollo de los proyectos regionales y los estudios de área, aparece un interés por el estudio de los sistemas de mercado regional, cuyas redes y flujos eran, según los autores de la época, la expresión más clara de una forma de integración espacial y sociocultural propia de los habitantes de una extensa área del Estado de Michoacán.

Aún en la actualidad los mercados de Michoacán siguen teniendo importancia como espacios de articulación social local, si bien las transformaciones en los mecanismos de intercambio económico han cambiado el sentido e importancia que tienen para las personas y su economía. El mercado de Paracho, por ejemplo, uno de los más importantes de la región junto con el de Pátzcuaro, atrae a las poblaciones colindantes de Cherán, Aranza, Ahuiran, Urapicho, San Felipe, Nurío y Cocucho.

West fue uno de los primeros en advertir la importancia de los mercados regionales en la configuración de los espacios tarascos, entregando las ideas básicas para una nueva forma de interpretar los procesos de integración territorial purhépecha: la existencia de un sistema de mercados, rutas y mercaderes profesionales (huacaleros) y arrieros. El sistema de mercado representa para West un importante factor de cohesión social entre los tarascos, siendo el mercado de Paracho el más importante de los mercados existentes en el centro de la Meseta y de la región purhépecha en general. Esta cuestión será retomada algunos años después en el trabajo de Beals y Durston. Al respecto, Beals señalaba la existencia de dos sistemas de mercado, uno interno, que a su vez está vinculado a un sistema de mercado mayor en pueblos mestizos como Uruapan y Pátzcuaro.

El sistema de mercados proveía de diversos productos intercambiados entre pue- blos que poseían distintos recursos o bien la oportunidad de compraventa de productos provenientes de la economía nacional, es decir, de otras regiones del país, de la industria manufacturera, etc. En cuanto a los mercados internos, Beals señala que dependiendo de la altitud a la que están ubicados algunos pueblos o de la preferencia alimenticia de sus habitantes, estos podían proveer de diversos productos que un pueblo vecino no poseía ${ }^{49}$. De este modo los mercados encadenan a pueblos y cabeceras y a través de estos flujos y de los espacios que estas relaciones conllevan se desarrollan formas de convivencia que identifican a grupos específicos dentro de la región.

A través del tiempo la regionalización del espacio purhépecha ha sido un factor recurrente, así como ha sucedido con el Plan Lerma de Asistencia Técnica de 1973, la Comisión Río Balsas, desde los años sesenta, y más recientemente con las acciones directas del Estado hacia los pueblos indígenas, como ocurre con los primeros pasos del indigenismo de participación y la formación de los Consejos Supremos a principios de los años setenta ${ }^{50}$.

Los Consejos Supremos son la expresión más clara de este vínculo entre las políticas de Estado y la práctica política propia de los purhépechas. La intención del INI era formar un Consejo Supremo Purhépecha pero las pugnas en las organizaciones agrarias purhépechas llevaron hacia fines de los años ochenta a la formación de dos Consejos Supremos: el de la Meseta y la Cañada y el de la Zona Lacustre. Este esquema de alianzas se ha mantenido en el imaginario indígena hasta hoy y se expresa claramente por ejemplo en la formación a principios de los años noventa de la organización Nación Purhépechas, que agrupa principalmente a comunidades de la Cañada y la Meseta. Se aprecia también en la Formación del Consejo de Autoridades Purhépechas de la Meseta, creado a mediados del año 2002 y queda aún más claro en la tendencia creciente de las organizaciones de la Zona Lacustre a vincularse con el gobierno del estado a partir de la última década, sobre todo con la creación de situación de los principales líderes de la zona lacustre al gobierno del gobernador

\footnotetext{
$49 \quad$ Velas, op. cit., p. 733.

50 Los Consejos Supremos se inician en todo el país luego del primer Concejo Nacional de Pueblos Indígenas (CNPI) realizado en Janitzio, Michoacán.
} 
Lázaro Cárdenas Batel a través de la Oficina para la Representación de los Pueblos Indígenas del Estado.

Por otro lado, hasta el año 2003 la labor del INI, labor que ha continuado hasta hoy la Comisión Nacional para el Desarrollo de los Pueblos Indígenas (CDI), seguía regionalizada en la estructura básica de tres regiones: la Meseta, la Cañada de los Once Pueblos y la Zona Lacustre. La expresión más clara de esto era la distribución y organización de los Fondos Regionales (para el desarrollo indígena), que repiten nuevamente esta estructura regional y que obliga a las comunidades a agruparse en torno a estas estructuras que tienen una clara orientación burocrática, aunque dicen recoger una "realidad" territorial preexistente y con profundo sentido histórico.

Pero tal vez lo más relevante de los proceso de construcción de los territorios étnicos en Michoacán pueda ser la construcción que los propios indígenas a través de sus movimientos sociales han realizado. En este ámbito la apropiación simbólica se relaciona estrechamente con los procesos políticos, las demandas económicas y los reclamos por el reconocimiento de derechos. La simbólica indígena en particular se encuentra en el centro de las formas de apropiación, el discurso étnico releva símbolos, imágenes y representaciones mediante los cuales los purhépechas, sus organizaciones y líderes buscan la integración de una comunidad dispersa y fragmentada por siglos de transformaciones, pero sobre todo representa un espléndido esfuerzo por resistir las fuerzas del mercado en la era del noeliberalismo que ve los territorios indígenas como un residuo o como un ámbito de ampliación de sus mecanismos de producción y explotación de recursos.

Territorio, simbolismo y política: las nuevas formas de apropiación del espacio entre los purhépechas

[Demandamos] El reconocimiento constitucional de nuestros territorios y tierras ancestrales que representan la totalidad de nuestro hábitat en donde reproducimos nuestra existencia material y espiritual como pueblos, para conservarlos íntegramente y mantener la tenencia comunal de nuestras tierras, pues solo así es posible preservar nuestra cohesión social, conservar las formas de trabajo gratuito y colectivo en beneficio de toda la comunidad y asegurar el patrimonio y el futuro de las próximas generaciones. Tercer Congreso Nacional Indígena, Declaración de Nurío, Michoacán, marzo, 2001.

El movimiento purhépecha, como otros movimientos indígenas de México y América Latina, ha ampliado el campo de significados asociados al espacio y el territorio. En el discurso etnicista el territorio localiza las identidades, enmarca los procesos políticos que buscan la autonomía y los convierte en un puente desde el cual negociar y dialogar con el Estado. En este ejercicio de politización del territorio los indígenas esencializan su vínculo con la tierra y la naturaleza buscando explicar a través de él su antigüedad y su legitimidad frente al Estado. Zárate señala que todas las agrupaciones $u$ organizaciones políticas desarrollan algún tipo de simbolismo que les confiere una identidad propia y norma la conducta de sus miembros, luego agrega que en el caso de los grupos que se asumen como étnicos no solo implica la posibilidad de alcanzar un estatus específico en la negociación frente al Estado, sino también la posibilidad o la voluntad de utilizar esos símbolos proveniente del gru$\mathrm{po}^{51}$. Los símbolos, entonces, están al servicio de las disputas de poder, ellos remarcan las demandas y los contenidos más profundos que definen su lucha.

La etnicidad es en este ámbito un campo politizado que se sirve de los valores y las disposiciones profundas, pero también actúa como un abanico de posibilidades estratégicas e instrumentales ${ }^{52}$, de ahí que las luchas étnicas en sus momentos más álgidos o de crisis aparezcan saturadas de simbolismos y significados.

51 Zárate Hernández (1993), op. cit., p. 23

52 En cuanto a la etnicidad como estrategia véase: Michiel Baud; Kees Koonings, Gert Oostindie, Arij Ouweneel y Patrico Silva (1996), Etnicidad como estrategia en América Latina y el Caribe, Quito, Abya-Yala; Christian Gros (2000), Políticas de la etnicidad: Identidad, estado y modernidad, Bogotá, Instituto Colombiano de Antropología e Historia; y Álvaro Bello (2004), Etnicidad y ciudadanía en América Latina, Santiago, CEPAL. 
Esto es lo que ha sucedido con los simbolismos del territorio, que enmarcan casi todas las formas de simbolización política posible elaboradas por los purhépechas durante los años noventa. Se trata del interés común de los purhépechas, de lo que ellos definieron en algún momento como su prioridad en su lucha con el Estado, por eso desean generar una carga simbólica que pueda desplazar otros símbolos menores o secundarios. Sin embargo, estos símbolos pueden cambiar, es claro que en los últimos años el discurso de la autonomía y la autodeterminación, si bien tiene un trasfondo territorial, remarca otras pulsiones, enclavadas más bien en la cuestión del poder político.

Ahora bien, el cruce con la historia, la memoria y la construcción identitaria ha agregado nuevos significados a las formas de apropiación del espacio ampliando el rango de simbólico que conforman las representaciones espaciales. El resultado de esta ampliación de significados es el territorio étnico, el soporte espacial de la reconstrucción y reinvención de la identidad étnica de los purhépechas, proceso que, como hemos señalado, no se produce de manera aislada, sino con relación a los cambios estructurales sufridos por el campo mexicano, así como por las nuevas formas de diálogo y conflicto impulsadas por el Estado a través del indigenismo, así como la mayor difusión de los procesos estimulados por la globalización. No se trata de una relación causal entre distintos elementos, sino de procesos de mutua influencia en diferentes momentos y con distintos grados de intensidad.

Nurío no ha estado al margen de estos procesos, por el contrario, ha sido un actor activo en la reconstrucción del territorio purhépecha. Tanto los intelectuales y líderes de Nurío, así como su organización comunal han participado de manera directa en la política étnica supralocal, han formado alianzas con otras comunidades superando así la fragmentación insular del territorio purhépecha para dar vida a una práctica política territorializada cuyo eje representacional ya no es solo el espacio comunal, sino que la figura del gran territorio, como es la Meseta.

Hoy día las organizaciones y líderes purhépechas señalan que la única forma de contrarrestar el peso del Estado, de buscar formas autónomas de gobierno o de negociar mejores beneficios para ellos, incluido el fin de los conflictos agrarios, pasa por la reconstrucción del territorio que los antiguos purhépechas poseyeron. El territorio sería el soporte para la reconstrucción identitaria, pero también lo sería para el autogobierno y la autogestión. El territorio simboliza la identidad como pueblo y comprende las áreas geográficas o espacios de la naturaleza que se encuentran bajo la influencia cultural y el control político del pueblo ${ }^{53}$. En el discurso étnico el territorio es un derecho que "implica el poder disponer del libre uso y disfrute de los recursos naturales, renovables y no renovables, del espacio aéreo y ser beneficiarios directos de ellos" ${ }^{54}$. La Organización Nación Purhépecha, tal vez la de mayor influencia en la reinvención del territorio, señala además: "La lucha por nuestro territorio marca y simboliza nuestra identidad como pueblos, por eso luchamos y nos resistimos a perder los que históricamente nos corresponde" 55 .

\section{La simbolización y politización purhépecha del territorio}

La regionalización del territorio purhépecha se encuentra en la práctica política de los propios sujetos. La práctica política la entiendo no solo como el conjunto de acciones y discursos que constituyen una actividad pública orientada a la consecución de recursos, entre los cuales se encuentra el poder, sino como un conjunto de representaciones y símbolos que expresan esas prácticas, que le dan sentido y que orientan el accionar colectivo. En este caso la práctica etnopolítica de los purhépechas, según creo, ha buscado diversas formas de ritualizar y simbolizar los elementos básicos de sus demandas, como el territorio y la tierra. Si se analizan algunos de estos rituales se puede observar que detrás

\footnotetext{
53 Amparo Gutiérrez, Ley para los Pueblos Originarios, propuesta de Organización Nación Purhépecha.

54 "Autonomía Regional. Un proyecto de pervivencia para el Pueblo Purhépecha y para los pueblos indígenas de México", Follero, Organización Nación Purhépecha.

55 Ibid.
} 
se encuentra una idea fuerza permanente: el territorio. ¿Pero qué territorio? Al parecer no es un territorio del todo nuevo, sino más bien uno reinterpretado a la luz de las políticas indigenistas.

El Año Nuevo Purhépecha es un ritual, una ceremonia reinventada que se realiza en las tierras michoacanas desde $1983^{56}$. Eduardo Zárate señalaba hace algunos años que el Año Nuevo Purhépecha es la fiesta más representativa del moderno renacimiento étnico de los purhépechas, pues a través de ella los purhépechas intentan representar una cierta "realidad" que a la vez oculta las diferencias sociales y los conflictos políticos. De este modo el año nuevo plantea la posibilidad de una visión consensual en torno a una visión de mundo compartida: la de los purhépechas. De esta manera, la fiesta recupera y "recuerda" el pasado glorioso por medio del cual se quiere reforzar lo límites y fronteras culturales que permiten dar legitimidad a las demandas políticas de los purhépechas actuales ${ }^{57}$.

El Año Nuevo Purhépecha cumple con varios propósitos, entre otros, el de oponerse al Año Nuevo oficial, al de los blancos, al de la cultura de Occidente. A través de esta oposición o contraste se intenta demostrar que el Año Nuevo de los purhépecha es un año "verdadero", basado en la naturaleza y en la tradición, a diferencia del Año Nuevo oficial, realizado por convención y de manera "artificial". El Año Nuevo Purhépecha fue creado por un grupo de profesionistas y líderes indígenas de la zona de la Laguna y un párroco de uno de los pueblos que rodea a la Laguna ${ }^{58}$.

La celebración se realiza el día 1 de febrero de cada año hasta las primeras horas del día 2 de febrero, coincidente con la fiesta católica de la Candelaria. El paso del viejo al nuevo año se simboliza con el encendido de una gran fogata que los purhépechas llaman el "Fuego Nuevo", que representa al antiguo dios de los purhépechas, Curicaveri. La costumbre de prender fuego en la puerta de las casas de los pueblos purhépecha es de antigua data y en algunas localidades aún se sigue realizando. El encendido del "Fuego Nuevo" se realiza normalmente cerca de las doce de la noche y debe coincidir con la posición de dos estrellas que se ubican en el cenit alrededor de esa hora. Para ubicar las estrellas en el firmamento, se instalan dos pequeños telescopios con los cuales algunas personas encargadas se ocupan de rastrear el curso de las estrellas hasta su ubicación en su punto más alto. Pregunté si este interés por fundamentar de manera astral la fiesta provenía de las antiguas tradiciones purhépecha, pero uno de los promotores y organizadores de la fiesta, Gilberto Jerónimo Mateo, me contó que se debía a que uno de los creadores de la ceremonia, el cura párroco de Santa Fe de la Laguna, era una persona aficionada a la observación de las estrellas y poseía un telescopio en los tiempos que comenzó a realizarse, él fue quien introdujo esta "tradición" 59 . De hecho en la primera fiesta, realizada en Tzintzuntzan e Ihuatzio por personas de Santa Fe en 1983, se inscribieron en la piedra-símbolo "dos estrellas que al atardecer se hicieron más visible en el cielo". En la fiesta de San Juan Nuevo, en febrero del 2003, el encendido del "Fuego Nuevo" se realizó cerca de la una de la madrugada, hora en que las estrellas se ubicaron justo en el cenit ${ }^{60}$.

La ceremonia del Año Nuevo se realiza en torno a una piedra de cantera de forma piramidal en cuyas caras se van inscribiendo los símbolos de las comunidades en las que se realiza la festividad. La piedra, junto con otros símbolos, como un pez de cantera que representa a los pueblos de la Laguna y una hermosa flecha de obsidiana, encontrada en un sitio arqueológico, se ubican en un lugar visible para que todos quienes lo deseen la puedan admirar y tocar, y junto a ellas se

\footnotetext{
56 Un análisis sobre los significados políticos y los actores involucrados en una ceremonia reinventada como el Año Nuevo Purhépecha, en Zárate Hernández, Eduardo (1994), "La fiesta del año nuevo Purhépecha como ritual político. Notas en torno al discurso de los profesionistas indígenas purhépechas", en Andrew Roth y José Lameiras (eds.), El verbo oficial, Guadalajara, El Colegio de Michoacán/ITESO.

57 Zárate Hernández (1993), op. cit., pp. 31-38.

58 Entrevista con GJM, Morelia.

59 Entrevista con GJM, Morelia.

60 Notas de campo, Año Nuevo Purhépecha de San Juan Nuevo, 1-2 de febrero de 2003.
} 
ubican ofrendas de todo: botellas de tequila, panes dulces, flores, pequeñas piedras y dibujos hechos por niños. Al igual que en las ceremonias católicas de la región, quienes tienen la responsabilidad de cuidar y trasladar los símbolos del Año Nuevo, son llamados "cargueros". Desde temprano en la mañana del día $1^{\circ}$ comienzan a llegar personas de distintos lugares de la región purhépecha, familias completas descienden de los autobuses y se van ubicando en los espacios destinados a la celebración. En algunos casos la fiesta se inicia con una misa en la iglesia principal, aunque esto no es visto con buenos ojos por todos los organizadores, algunos piensan que la fiesta solo debiera aludir a la "liturgia purhépecha", así ocurrió en el caso de San Juan Nuevo, pese a que de todos modos se realizó la misa en el concurrido santuario del lugar.

Las actividades continúan durante el día con la presentación de bandas y conjuntos musicales que interpretan reiteradamente sones abajeños y música local de raíz purhé, a lo largo de la tarde se van sucediendo grupos de danza de escuelas primarias, pireris o cantantes, recitadores y cuentistas, en medio de una mar de gente que repleta la plaza central del pueblo, ahí se dan cita campesinos venidos de lejanos lugares, chavos y cholos ${ }^{61}$, que parecen ajenos al ceremonial y etiqueta que los organizadores desean dar al evento. Con el transcurrir de las horas, las calles, changarros y comercios adyacentes se van llenando de curiosos citadinos atraídos por la propaganda aparecida los días anteriores en "letreros espectaculares", financiados por el gobierno del estado, y en los noticiarios de TV y periódicos locales. Para muchos de los asistentes el evento es más bien un espectáculo folclórico, sin mayores significados. Así, hasta la noche diversos números musicales, danzas, pirekuas, poetas locales y discursos resaltan el "orgullo purhépecha" en un ambiente festivo y alegre ${ }^{62}$.
La primera celebración del Año Nuevo Purhépecha se realizó en 1983 en Tzintzutnzan e Ihuatzio, en 1984 se hizó en Ihuatzio, en 1985 se llevó a cabo en Nurío, en 1986 se efectuó en San Andrés Tziróndaro, en 1987 se fue en Angahuan, 1988 en Pichátaro, 1989 en Tacuro, en 1990 en Santa Fe de la Laguna, en 1991 Cheranástico, en 1992 en Ichupio, en 1993 en se celebró en la comunidad de Cocucho, en 1994 en la comunidad de Ucazanástacua, en 1995 en Tarecuato, en 1996 se realizó en la comunidad de Puácuaro, en 1997 en Sevina, en 1998 en Janitzio en el Lago de Pátzcuaro, en 1999 en San Lorenzo, en el 2000 en Tiríndaro, en el 2001 en Cherán, en el 2002 en Carapan, en el 2003 en San Juan Nuevo, donde se decidió que la celebración próxima se realizaría en Pátzcuaro.

Los intelectuales purhépecha, creadores de esta fiesta de la "purhepechidad" como la ha llamado Eduardo Zárate, señalan que con ella se busca recuperar y refuncionalizar los valores de la cultura purhépecha. ${ }^{63}$

El ritual del Año Nuevo Purhépecha contiene elaborados y profundos significados que aluden a la afirmación étnica, a la valorización de las tradiciones locales, de la historia y "la costumbre", pero además, en mi opinión puede ser interpretado como un ritual que intenta destacar el valor del territorio como un factor claramente conectado a la identidad étnica purhépecha. Los intelectuales purhépechas señalan que la festividad se realiza cada año "procurando que no coincida en forma consecutiva en una misma región geográfica, de las cuatro en que tradicionalmente se subdivide el territorio purhépecha: Sierra, Lacustre, Ciénega y Cañada de los Once Pueblos" ${ }^{64}$. Pero este cuidado en trasladar la fiesta de una región a otra no es simplemente una acción de equidad y alternancia, sino que remite a la idea de que la fiesta sea, en si misma, como diría Raffestin, un acto de implantación de

\footnotetext{
61 Los cholos son jóvenes y adolescentes que se agrupan en pandillas o bandas, generalmente están compuestas por hijos de migrantes retornados o ex migrantes jóvenes que replican las prácticas de agrupamiento y estética que se dan en ciudades de los Estados Unidos como Los Ángeles (California). Los cholos visten como rapers, con prendas amplias, camisetas de algún equipo de fútbol americano y una gorra tipo jockey.

62 Notas de campo, Año Nuevo Purhépecha, San Juan Nuevo, 1-2 de febrero de 2003.

63 Juan Velázquez, Gilberto Jerónimo, Edelmira Estrada, Raúl Máximo (1998), Vocabulario práctico bilingüe p’urhépechaespañol, Morelia, Dirección General de Culturas Populares, INEA-Michoacán, PACMYC-Michoacán, p. 128.

64 Idem., p. 131.
} 
nodos de confirmación cultural e identitaria, que opera de manera simbólica y que va tejiendo una red y una malla sobre la cual se configura el territorio de los purhépechas. La piedra misma, en la que se inscriben -de manera literal- los símbolos de las comunidades en las que año tras año se efectúa la fiesta, es un "mapa" metonímico del territorio purhépecha, que ratifica la materialidad de ese territorio, un mapa que por cierto va creciendo año con año en un proceso de recuperación o reconfiguración simbólica del antiguo territorio purhépecha.

En la medida que los límites y fronteras territoriales purhépecha se han ido haciendo más difusas, más débiles, como producto de la penetración mestiza, la heterogeneidad de la sociedad michoacana en general, la pérdida de la lengua y las costumbre, la migración a los Estados Unidos y sus consecuentes efectos en los patrones culturales, la fiesta del Año Nuevo actúa como una ritual de confirmación de la purhepechidad efectuado conforme a patrones territoriales predeterminados y acordados entre los líderes, intelectuales y profesionistas purhépechas. Un acto que al trasladarse de un lugar a otro, "dentro" de la región purhépecha, reinscribe o reconoce elementos de la cultura y la identidad entre quienes reciben el favor o la gracia de realizar la fiesta.

La decisión sobre cuál es la próxima comunidad que recibirá los símbolos y que por lo tanto tendrá la responsabilidad de realizar la fiesta, se decide en una reunión el mismo día de la celebración. A esta reunión solo pueden asistir los miembros del "consejo de apoyo", entidad que está encargada de la organización general del ritual, y los representantes, autoridades y líderes de las comunidades interesadas en que la ceremonia se lleve a cabo en sus tierras. En la fiesta realizada en San Juan Nuevo la reunión de discusión duró casi cinco horas, y a pesar de que no pude ingresar obtuve algunas informaciones sobre el tenor de la discusión. La discusión se prolongó debido a que dos de las comunidades postulantes cuestionaron la purhepechidad del candidato más fuerte, Pátzcuaro, bajo el argumento de que esta población, ubicada a orillas del lago del mismo nombre, ha perdido sus tradiciones, la lengua y la cultura purhépecha, lo que la hace menos merecedora del cargo. La discusión adquirió mayor complejidad porque los solicitantes son migrantes de comunidades de la Sierra y la Laguna, establecidos en Pátzcuaro desde hace algunos años, esta situación, según los representantes de las otras comunidades, los descalificaba para ser peticionarios en nombre de Pátzcuaro. Gilberto Jerónimo Mateo, un activo dirigente purhépecha, presente en dicha reunión, señala que frente a este discurso, que en su opinión niega la realidad actual en que los miembros de la "gran comunidad purhépecha" se encuentran dispersos en distintas regiones del país y de los Estados Unidos, se debe pensar no en restringir o excluir la membresía, sino, por el contrario, en buscar formas de incluir a aquellas comunidades nuevas surgidas del éxodo y la migración, así, señala Jerónimo Mateo, uno de los principales promotores de esta fiesta a través de su Página Purhépecha ( $P$ 'urhepecha Jimbo) en el diario La Voz de Michoacán, sugiere que se debe reconocer esa realidad llevando la celebración del Año Nuevo Purhépecha hasta esos lugares. Así, en los próximos años, la celebración debiera realizarse en el D.F., en Baja California, en California o en Missouri, lugares donde se concentra la mayor parte de la población purhépecha fuera del estado de Michoacán ${ }^{65}$, con ello se ampliarían los límites y las coordenadas del mapa purhépecha, actualizándolo a sus formas actuales.

\section{Conclusiones}

Pero mi interés no se queda solo en el plano de las interpretaciones científicas y de la inducción. Mi principal interés se encuentra en la necesidad de entender, con las herramientas que entrega la antropología, la etnografía y la etnohistoria, por qué los pueblos indígenas, como sujeto complejo y diverso, en el contexto de sus modernas etnicidades, han centrado sus discursos, sus símbolos y sus prácticas políticas en el territorio. La respuesta en un principio pudo ser obvia, su vínculo con la tierra y su marcado apego territorial como producto de las condiciones históricas que han vivido han hecho que las nociones de espacio en general sean de gran importancia

65 Entrevista con GJM, Morelia. 
en la vida cotidiana y en sus prácticas políticas. Pero esta respuesta tiene mucho de tautología, es como decir: los indígenas se definen por su apego a la tierra, por lo tanto sin la tierra no son indígenas. Esa respuesta demasiado primordialista es la que me inquietó por largo tiempo. Años después descubrí que las primeras organizaciones indígenas en hacer alusión al concepto de territorio provenían de la zona amazónica. El concepto de territorio fue utilizado desde fines de los años setenta por organizaciones regionales como la Coordinadora de Organizaciones Indígenas de la Cuenca Amazónica (COICA) y organizaciones nacionales como la Central Indígena del Oriente Boliviano (CIDOB) para hacer frente a las invasiones de las tierras amazónicas ocupadas por pueblos cazadores-recolectores que no tenían o no podían demostrar la posesión de títulos de dominio sobre extensas áreas. Las comunidades argumentaban que ellos, a diferencia de otros pueblos, no poseían tierras delimitadas, sino que territorios donde cabían no solo las tierras para el cultivo o la habitación, sino que los bosques, las montañas, la fauna, los ríos, la mitología y los rituales.

Pocos años después, sobre todo desde principio de los años noventa, la mayor parte de las grandes organizaciones indígenas de América Latina habían incorporado el concepto de territorio, lo que se vio reforzado por el reconocimiento del concepto en el derecho internacional. Particular importancia ha cobrado la mención al territorio contenida en el Convenio 169 de la OIT, esta ha sido la base sobre la cual se han articulado discursos y argumentos sobre el territorio, tal como lo ha sido el debate sobre las autonomías, cuya base territorial es hoy por hoy indiscutible.

Todos estos procesos coincidieron con un interés de las ciencias sociales por abordar los temas relativos a la relación entre pueblos indígenas, cultura, espacio y territorio. El problema es que a la luz del debate político el discurso del territorio comenzó a darse por sobreentendido, como algo dado, que calzaba en forma natural con el carácter y la identidad indígena. Desde las propias ciencias sociales se comenzó a hablar de la relación entre territorio y cultura como si se tratase de una relación orgánica o natural con frases del estilo: "el territorio es parte fundamental de la identidad de tal o cual pueblo indígena", "la tierra y el territorio es el sustento de tal o cual sociedad", "los indígenas siempre han luchado por la tierra", etc.

En todo caso, mi propósito en este artículo no ha sido negar estas ideas, sino buscar el argumento desde donde se han formulado atendiendo a un caso específico como es el de los purhépechas de México.

\section{Bibliografía}

AGUIRRE BELTRÁN, G. (1952), Problemas de la población indígena de la Cuenca del Tepalcatepec (vols. I y II), Obra Antropológica III, Fondo de Cultura Económica, México.

AGUIRRE BELTRÁN, G. (1991a), Formas de gobierno indígena, Obra Antropológica IV, Fondo de Cultura Económica, México.

AGUIRRE BELTRÁN, G. (1991b), Regiones de refugio, Obra Antropológica IX, Fondo de Cultura Económica, México.

AGUIRRE BELTRÁN, G. (1995), Problemas de la población indígena de la cuenca del Tepalcatepec (vols. I y II), Obra Antropológica III, Fondo de Cultura Económica, México.

BARABAS, A. (2003), "Introducción: Una mirada etnográfica sobre los territorios indígenas simbólicos", en Alicia Barabas (coord.), Diálogos con el territorio. Simbolizaciones sobre el espacio en las culturas indígenas, INAH, México.

BARTH, F. (1976), Los grupos étnicos y sus fronteras, Fondo de Cultura Económica, México.

BAUD, M. et al. (1996), Etnicidad como estrategia en América Latina y el Caribe, Quito, Abya-Yala; Christian Gros (2000), Políticas de la etnicidad: Identidad, estado y modernidad, Instituto Colombiano de Antropología e Historia, Bogotá.

BELLO, Á. (2004), Etnicidad y ciudadanía en América Latina, CEPAL, Santiago.

BOURDIEU, P. (1991), El sentido práctico, Taurus, Madrid.

CARMAGNANI, M. (2004), El regreso de los dioses. El proceso de reconstitución de la identi- 
dad étnica en Oaxaca, siglos XVII y XVIII, Fondo de Cultura Económica, México.

CARRASCO, P. (1976), El catolicismo popular de los tarascos, SEPSETENTA, México.

COHEN, A. (1989), The symbolic construction of community, Routledge, London.

CRANG, M. (1998), Cultural Geography, Routledge, London.

CRANG, M. y N. Thrift (2000), "Introduction", en Mike Crang and Nigel Thrift (Ed.), Thinking space, Routledge, London.

DE CERTEAU, M. (2000), La invención de lo cotidiano, I Artes de Hacer, Universidad Iberoamericana, Instituto Tecnológico de Estudios Superiores de Occidente, México.

DE GORTAIRE, A. (1968), "La región tarasca: estudio de integración de áreas", en Anuario Indigenista 28: 25-32.

DE GORTARI, L. (1997), "Comunidad como forma de tenencia de la tierra", en Estudios Agrarios 8 (julio- septiembre): 99-120.

DE LA Peña, G. (1988), "Los estudios regionales", en C. García Mora (coord.), La antropología en México, Panorama histórico $N^{\circ} 4$, Cuestiones medulares (Etnología y antropología social), INAH, México.

DE LA Peña, G. et al. (1987), "Algunos temas y problemas en la antropología social del área purhépecha", en Antropología Social de la Región purhépecha, El Colegio de Michoacán, Zamora, México.

DE VOS, G. (1995), "Ethnic pluralism: conflict and acommodation", en L. Romanucci-Ros y G. De Vos (eds.), Ethnic identity, creation, conflict and acommodation, Altamira Press, Estados Unidos.

DESCOLA, PH. y G. Pálsson (coord.) (2001), Naturaleza y sociedad, perspectivas antropológicas, Siglo XXI, México.

DINNERMAN, I. (1974), Los tarascos, campesinos y artesanos de Michoacán, SEPSETENTAS, México.

DURSTON, J. (1992), Organización social de los mercados campesinos en el centro de Michoacán, INI, CONACULTA, México.
FOSTER, G. (1974), Las culturas tradicionales y los cambios técnicos, Fondo de Cultura Económica, México.

FRÉMONT, A. (1976), La région, espace vécu, Presses Universitaires de France, Paris.

GIMÉNEZ, G. (1994), "Comunidades primordiales y modernización en México", en G. Giménez y R. Pozas (coord.). Modernización e identidades sociales, UNAM, IIS, Instituto Francés de América Latina, México.

GIMÉNEZ, G. (2000), "Territorio, cultura e identidades: la región socio-cultural”, en Rocío Rosales Ortega (coord.), Globalización y regiones en México, México, UNAM, Facultad de Ciencias Políticas y Sociales, Porrúa, pp. 29-30.

GIMÉNEZ, G. (2001), "Cultura, territorio y migraciones: aproximaciones teóricas", en Alteridades, año $11, \mathrm{~N}^{\circ} 22$, julio-diciembre, pp. 5-14.

GUPTA, A. y J. Ferguson (1999), "Culture, power, place: Ethnography at the end an era", en A. Gupta y J. Ferguson (eds.), Culture, power, place, Duke University Press, Durham and London.

HARVEY, D. (1998), La condición de la posmodernidad. Investigación sobre los orígenes del cambio cultural, Amorrortu, Buenos Aires.

HIRSCH, E. (1997), "Introduction: Landscape: Between place and space", en Eric Hirsch and Michael O'Hanlon (Ed.), The anthropology of landscape, perspectives on place and space, Clarendon Press, Oxford.

HOFFMANN O. y F. Salmeron (1997), "Introducción. Entre representación y apropiación, las formas de ver y hablar del espacio", en 0. Hoffmann y F. Salmeron (coords.), Nueve estudios sobre el espacio. Representación y formas de apropiación, CIESAS, ORSTOM, México.

KEMPER, R. (1987), "Urbanización y desarrollo en la región tarasca a partir de 1940", en Antropología social de los Purhépechas, Zamora, El Colegio de Michoacán.

LEACH, E. (1977), Sistemas políticos de la Alta Birmania, Anagrama, Barcelona.

OEHMICHEN, C. (2001), "La comunidad extendida: propuesta para una reflexión antropológica”, en Antropológicas 17: 49-57. 
OEHMICHEN, C. (2005), Identidad, género y relaciones interétnicas, Mazahuas en la ciudad de México, UNAM, IIA, PUEG, México.

RAFFESTIN, C. (1980), Pour une geographie du pouvoir, Librairies Techniques, Paris.

RUBIN DE LA BORBOLLA, D. y R. BEALS (1940), "The Tarascan project: A cooperative enterprise of the National Polytecnic Institute, Mexican Bureau of Indian Affairs, and The University of California", American Anthropologist, XLII: 708-712.

SÁENZ, M. (1966 [1938]), Carapan, Gobierno de Michoacán, Morelia-México.

SPERBER, D. (1988), El simbolismo en general, Anthropos, Barcelona.

STANISLAWSKI, D. (1947), "Tarascan political geography", American Anthropologist, vol. 49, pp. 46-55.

STEWARD, J. (1955), Teoría y práctica de los estudios de áreas, Unión Panamericana, Washington D.C.

STEWARD, J. (1979), "Levels of sociocultural integration: An operational concept", en Cultural Change. The Metodology of multilineal evolution, University of Illinois Press, Chicago.

THOMPSON, J. B. (2002), Ideología y cultura moderna: Teoría crítica social en la era de la comunicación de masas, UAM, México.

VAN ZANTWIJK, R. (1974), Los servidores de los santos: la identidad social y cultural de una comunidad tarasca en México, INI-SEP, México.

VÁZQUEZ, L. (2003), "Construcción y deconstrucción de los pueblos indígenas bajo el nuevo espíritu del capitalismo", en Memoria 170: 49-54.

VELÁZQUEZ, E. (2001), "El territorio de los popolucas de Soteapan, Veracruz: transformaciones en la organización y apropiación del espacio”, en Relaciones 87, vol. XII: 15-47.

VELÁZQUEZ, J. et al. (1998), Vocabulario práctico bilingüe p'urhépecha-español, Morelia, Dirección General de Culturas Populares, INEA-Michoacán, PACMYC-Michoacán.
VIQUEIRA, C. (2001), El enfoque regional en antropología, Universidad Iberoamericana, México.

WARMAN, A. (1985), "Notas para una redefinición de la comunidad agraria", en Revista Mexicana de Sociología 3 (julio-septiembre): 5-20.

WEST, R. (1948), Cultural geography of the modern tarascan area, Institute of Social Anthropology, 7, Smithsonian Institution, Washington D.C.

ZÁRATE E. (1993), Los señores de utopía. Etnicidad política en una comunidad purhépecha, CIESAS/El Colegio de Michoacán , Guadalajara.

ZÁRATE, E. (1994), "La fiesta del año nuevo Purhépecha como ritual político. Notas en torno al discurso de los profesionistas indígenas purhépechas", en A. Roth y J. Lameiras (eds.), El verbo oficial, Guadalajara, El Colegio de Michoacán/ITESO.

\section{Folletos}

GUTIÉRREZ, A. (s/f), Ley para los Pueblos Originarios, propuesta de Organización Nación Purhépecha.

"AUTONOMÍA REGIONAL. Un proyecto de pervivencia para el Pueblo Purhépecha y para los pueblos indígenas de México", Folleto, Organización Nación Purhépecha. 